\title{
An econometric model for demand of pulpwood market in Brazil
}

\author{
Humberto Angelo ${ }^{1}$, Tomas V. Angelo ${ }^{2}$, Alexandre N. de Almeida ${ }^{1}$, Pedro G. A. Vasconcelos* ${ }^{1}$, Mauro \\ Magliano $^{1}$, Alexandre A. Brasil ${ }^{1}$, Álvaro N. de Souza ${ }^{1}$ \& Eder P. Miguel ${ }^{1}$ \\ ${ }^{1}$ Department of Forestry Engineering, University of Brasilia (UnB), DF, Brazil \\ ${ }^{2}$ Amsterdam school of economics, University of Amsterdam, Netherlands
}

\section{*Corresponding author: pedroguilherme.av@gmail.com}

\section{Abstract}

The pulp industry has a great importance to the economy of Brazil and despite of being one of the biggest producer in the world this industry is still expanding in the country. In spite of the importance of the planted forests as main source for the pulp industry and other products, pulpwood for the cellulose market has received little attention in Brazil. Therefore, the objective of this research is the study of pulpwood demand in Brazil from 1994 to 2016, using econometric tools, where the demand equation was specified and adjusted by the Ordinary Least Squares method. The results showed that pulpwood price and the capacity of the pulp industry explain the pulpwood demand with good econometric results. The pulpwood demand is inelastic to price fluctuations and elastic to installed capacity. These results are consistent with the international estimations and they can assist projecting policies that promote more rational and sustainable management of the wood and consequently the forests.

Keywords: Pulpwood, Demand, Econometrics.

Introduction

The planted forests sector contributes to the Brazilian economy and to the society with an important share in the generation of products, taxes, jobs, and well-being. The sector is strategic in supplying raw materials and products for export and it also directly favours the conservation and preservation of natural resources (ABRAF, 2013).

In Brazil, the sector presents particular characteristics due to the country being one of the main holders of abundant forest resources. It is also the only one that has an extensive tropical forest area. Climate, soil characteristics, amount of sunlight and the development of forest technologies give Brazil an unprecedented competitive advantage in forest growth (BRACELPA, 2007). In 2013, the Brazilian planted trees sector added $\mathrm{R} \$ 56$ billions to the Brazilian Gross Domestic Product ( $R \$ 4.8$ trillions), representing $1.2 \%$ of all the wealth generated in the country (BRACELPA, 2014). In 2012, growth in the sector was $5.9 \%$, while Brazil closed the year with a $2.3 \%$ growth rate. Exports totalled USD 7.5 billion in 2012, and the pulp sector was responsible for generating USD 4.706 billion in foreign currency. The sector also supported about 4.4 million direct and indirect jobs (ABRAF, 2013).

The Gross Value of Forest Production for the segment of planted forests and integrated production chains (pulp and paper, wood industry, reconstituted panels, furniture, coalfired iron) in 2012 was around $\mathrm{R} \$ 56.3$ billion, with an estimated tax collection of approximately $\mathrm{R} \$ 7.6$ billion, according to ABRAF (2013) data.
Given the significant presence of the forestry sector in Brazil and the world, as well as the consolidation of Brazil in the international pulp and paper market, a continuous study is needed on the timber market in logs, the pulp production chain, their interdependences and the sector response worldwide. In the literature, some papers deal with the pulpwood market for pulp production in the United States and the Nordic countries, such as Leuschner (1973), Adams (1975), Brännund et al. (1985), Kuuluvainen (1986), Newman (1987), Carter (1992), Hetemäki and Kuuluvainen (1992) and Polyakov et al. (2005). For the Brazilian reality, we can cite the studies of Ângelo (2009) and Almeida (2006). For the demand for wood, we expect an inelastic response to the quantity demanded against a price variation. Since paper made of timber has few substitutes and has difficulty expanding its use for a wide variety of purposes, except for energy and reconstituted panels, the price should not significantly affect the quantity demanded. Almeida (2006) estimated the price elasticity of demand for pinewood for mechanical processing in the state of Paraná and found elasticity in the order of -0.55 , which is similar to that found in the United States by Newman (1987). In Sweden and Finland, the estimated price elasticities of demand are close to the unit (Newman, 1987; Kuulauinen, 1986; Danniels and Hyd, 1986, Braunnund et al., 1985, Stier 1980, Montgomery et al., 1975). Greater competition for wood in the various forest-based industries (energy, pulp and mechanical 
Table 1. Results of the pulpwood demand model for pulp production for the years 1994 to 2016.

\begin{tabular}{|c|c|c|c|c|c|}
\hline & Determinants & $\begin{array}{l}\text { Estimated } \\
\text { coefficient }\end{array}$ & Standard Error & T Test & P Value \\
\hline & Constant & 0.15 & 0.64 & 0.24 & 0.81 \\
\hline$P_{t}$ & Price of pulpwood in logs in year $t\left(R \$ / \mathrm{m}^{3}\right)$ & -0.23 & 0.09 & -2.55 & 0.02 \\
\hline $\mathrm{K}_{\mathrm{t}}$ & Installed capacity of pulp industry in year t (ton) & 0.93 & 0.14 & 6.67 & 0.00 \\
\hline $\mathrm{VI}_{\mathrm{t}}$ & World value of pulp imports in year $t$ (US\$) & 0.28 & 0.13 & 2.11 & 0.05 \\
\hline $\mathrm{R}^{2}$ & $\mathrm{R}^{2}$ & 0.89 & - & - & - \\
\hline $\mathrm{R}^{2}$ ajust & Adjusted $\mathrm{R}^{2}$ & 0.88 & - & - & - \\
\hline $\mathrm{n}$ 웅 & Number of observations & 25 & - & - & - \\
\hline $\mathrm{F}$ & F Test & 59.79 & - & - & 0 \\
\hline $\mathrm{EE}$ & Estimated Error & 0.10 & - & - & - \\
\hline
\end{tabular}

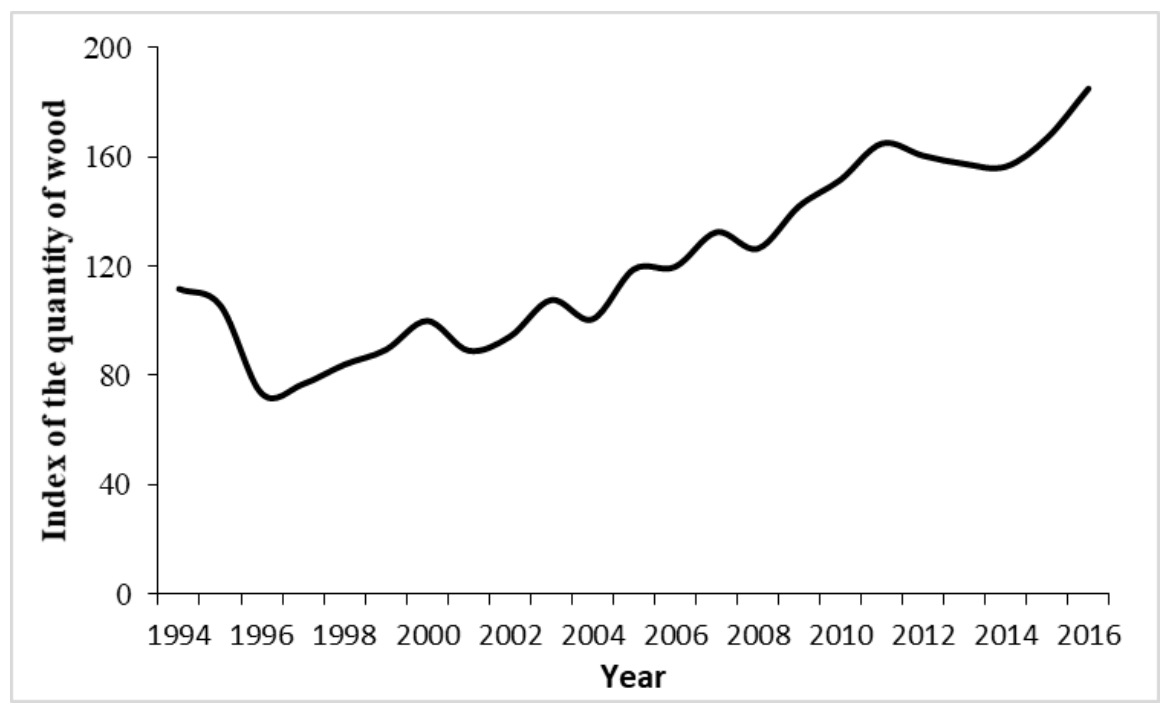

Source: IBGE (2018).

Fig 1. Evolution of the quantity of wood in logs from 1994 to 2016, $2000=100$.

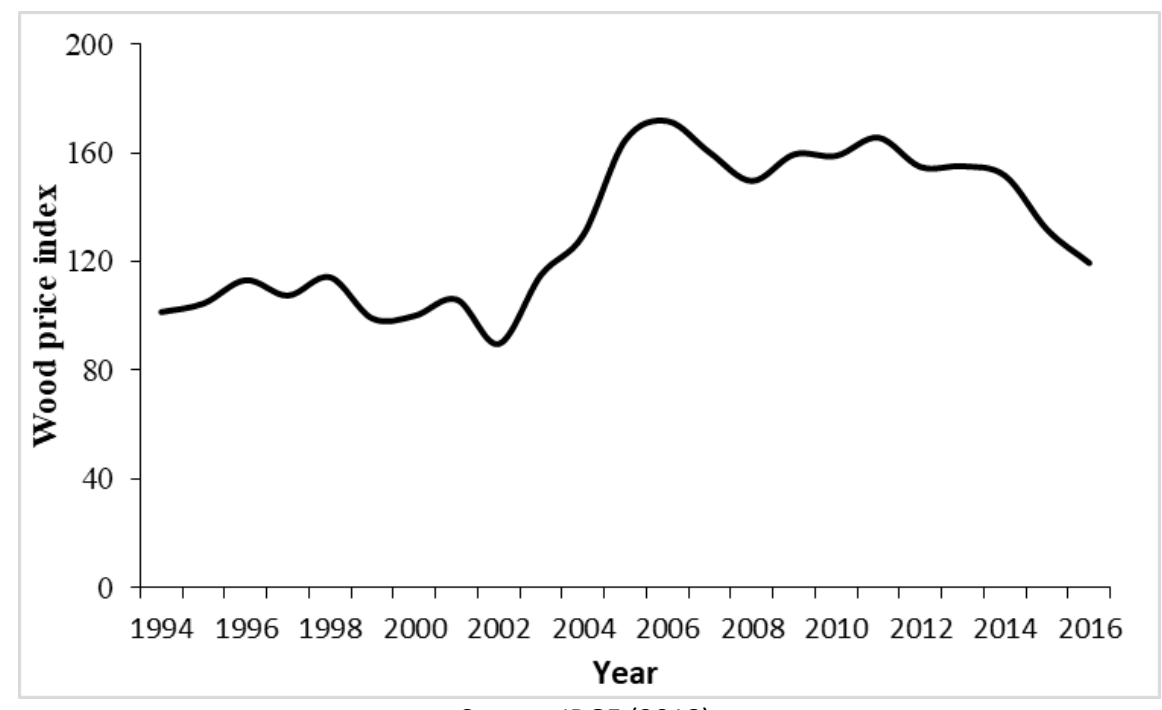

Source: IBGE (2018).

Fig 2. Evolution of the real price of timber for pulp production from 1994 to $2016,2000=100$. 


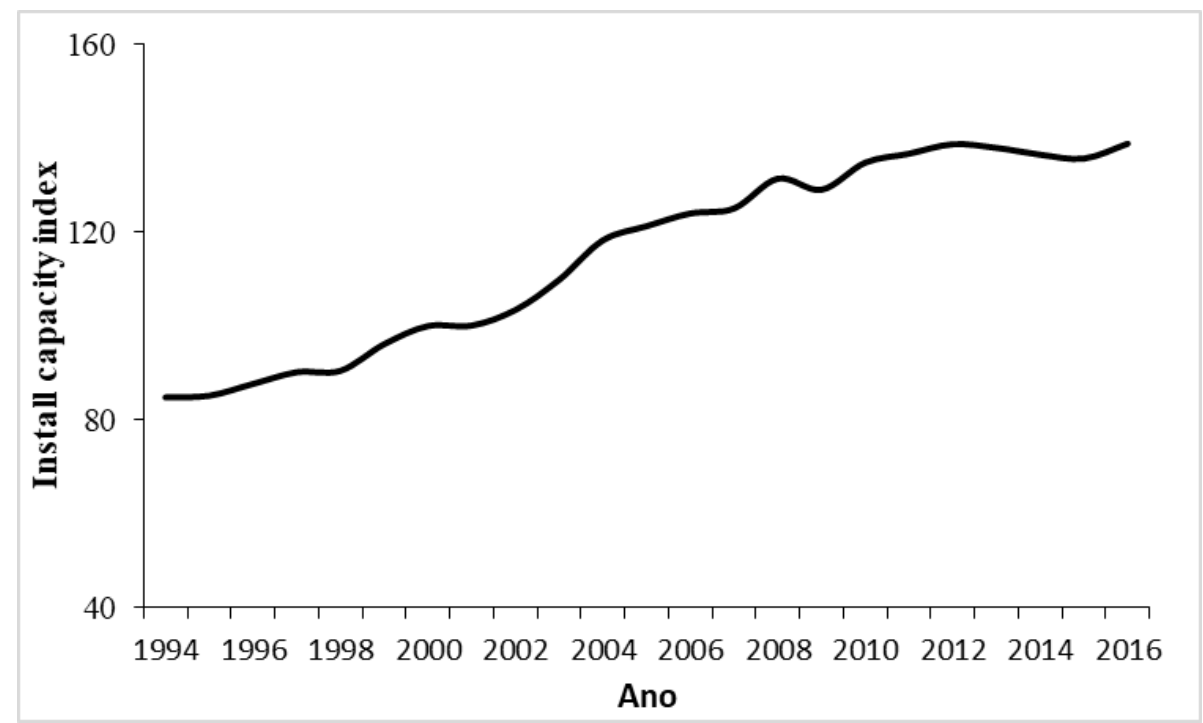

Source: IBGE (2018).

Fig 3. Evolution of the installed capacity of the industry from 1994 to $2016,2000=100$.

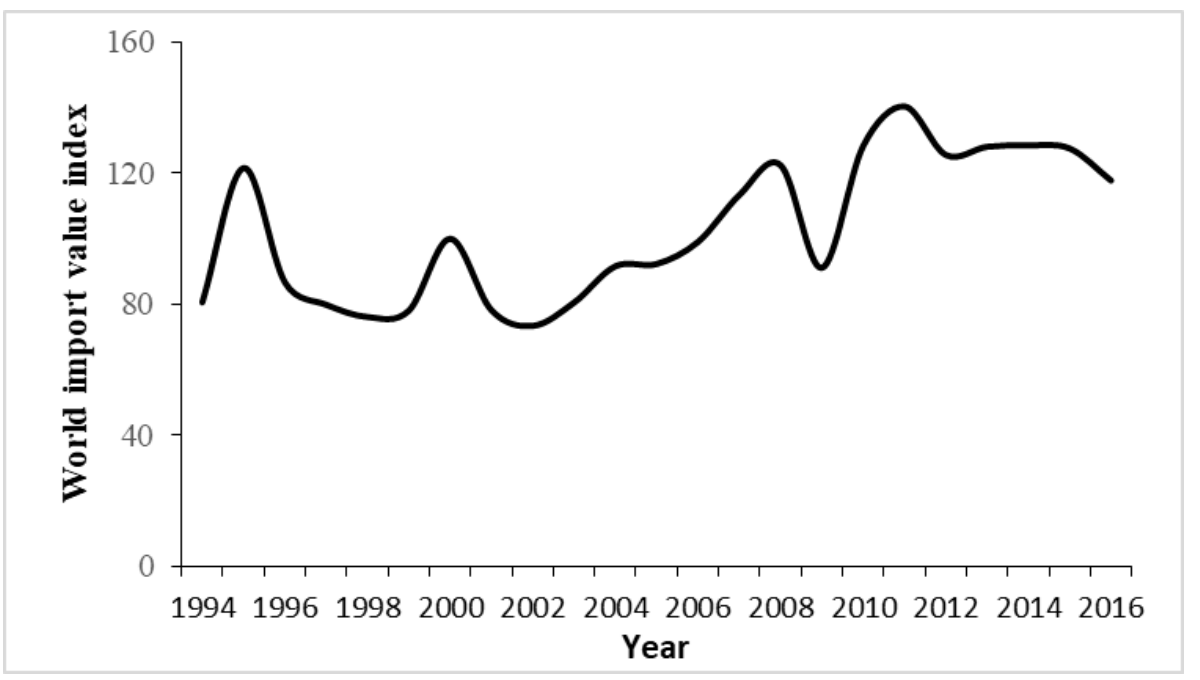

Source: IBGE (2018).

Fig 4. Evolution of the world import value in the period from 1994 to $2016,2000=100$.

processing) in the Nordic countries probably justifies a more resilient response of the quantity demanded to price changes. In view of the above, this work aims to contribute with important information on the determinants that affect the demand of wood in logs for pulp production in Brazil. Moreover, we estimate an econometric model of demand for the wood pulp market for pulp production to determine the elasticities of the main variables affecting that market.

\section{Results}

The estimated equation is reproduced in Table 1 . The values found for the coefficient of determination $\left(R^{2}\right)$, for the $t$ and $F$ tests and other statistics are given for the estimated equation. The coefficients showed the expected signs. An indirect relation was found with price and a direct with the installed capacity and world value of pulp imports. All variables were significant with a level of significance equal to or less than $5 \%$. The coefficient of determination (adjusted $\mathrm{R}^{2}$ ) was $88 \%$, which indicates that $88 \%$ of the variations observed in the pulp demand are explained by the pre-determined variables of the model. The F-test rejects the joint hypothesis that all coefficients are simultaneously equal to zero at a significance level of less than $1 \%$. Before starting the discussions on elasticities, it should be noted that all the results presented here are empirical, and all elasticities are analysed separately, which is called ceteris paribus in economics. This means "with other conditions remaining the same". In practice it hardly occurs, and the use of this type of result has to be always interpreted with care and caution in its practical use.

The price of timber log had an extremely low impact on wood demand. If the price index increases by one percentage point, 
the quantity demanded decreases by 0.23 percentage points. The estimated price elasticity of wood demand for pulp was 0.23 , characterizing demand as highly inelastic. This factor reflects the low influence of prices on the demand of wood by the pulp and paper industry, since this is a high fixed cost industry and its production is not very sensitive to oscillations in the wood price.

\section{Discussion}

The price elasticity resembled the values found by Stier (1980) and Montgomery et al. (1975) in the United States and by Ângelo, et al. (2009) in Brazil, where the price elasticity of the demand obtained was equal to -0.29 . On the other hand, Leuschner (1973) and Polyakov et al. (2005) found no relation to the price of wood and suggested models only with installed capacity as the main explanatory variable. In this context, other researches are suggested for a better understanding of the effect of the price of wood for pulp in the Brazilian market. The installed capacity (K) significantly influenced the demand for wood logs, in which the signal was expected by the theory. If the installed capacity utilization of the industry is increased by $1 \%$, the demand for wood will increase by $0.93 \%$. This fact indicates that, in periods of boom of the economy and expansion of the pulp industry, there is an increase in the demand for wood, according to the theory. An econometric analysis performed by Leuschner (1973) on the pulpwood market in Wisconsin (USA) used annual data between 1948 and 1969. Only the installed capacity variation was used as an explanatory variable for demand, disregarding the price of wood because of the high operating costs of pulp and paper mills. This led to the conclusion that, in the short run, the demand for pulpwood does not fluctuate with price. According to Angelo et al. (2009), it should be added that much more important than the price of wood for the paper and sheet metal industry is the guarantee of the supply of raw material since the production of these companies requires high fixed costs in the installation of their factories. Consequently, managers must ensure that they operate continuously. The variable value of world pulp imports had an extremely low impact on wood demand. If this index increases by one percentage point, the quantity demanded increases by only 0.28 percentage point. The estimated elasticity of the variable was 0.28 , characterizing the demand as inelastic. The significance of this variable indicates that fluctuations in wood demand depend on income and other economic conditions in the rest of the world, albeit of modest magnitude. In summary, the demand for timber by the pulp industry can be explained by the price of timber, the installed capacity and the world value of pulp imports.

\section{Materials and methods}

\section{Materials}

The material used is information on the production and commercialization of wood for pulp, including log products from Pinus and Eucalyptus. Its determinations of shape, volume and density are pre-specified according to the technical requirements of the industrial equipment and characteristics of the final product to be produced, such as cellulose pulp and paper. Timber for pulp is considered within a certain economic radius, for the extraction of pine and eucalyptus. The product originated from the wood in log is the cellulose, whose use goes from the manufacturing of paper to the composition of packaging, paints and hospital instruments. This product is part of a market defined by an oligopsonic structure between pulp and timber producers (Marques, 2012).

The theory that best fits the Brazilian forest market considers a model, in which the price and the quantity demanded are determined by a demand function with finite price elasticities (Brazil, 2002, Raimundo, 2001, Angelo e Silva, 1998; et al., 1998).

The demand function was specified as follows:

$\operatorname{Ln} Q^{d}{ }_{\mathrm{t}}=\beta_{0}+\beta_{1} \operatorname{Ln} P_{\mathrm{t}}+\beta_{2} \operatorname{LnK_{\mathrm {t}}}+\beta_{3} \operatorname{LnVI_{\mathrm {t}}}+e_{\mathrm{t}}$

In which:

$Q_{t}^{d}=$ Quantity demanded of wood logs for pulp in year $t$ in $\mathrm{m}^{3}$; $P_{t}=$ Price of timber for pulp production in year $t$ in reais; $K_{t}=$ Installed capacity of the pulp industry in year $t$ in tons per year; $\mathrm{VI}_{\mathrm{t}}=$ World value of imports of pulp in year $\mathrm{t}$ in dollars; $e_{\mathrm{t}}=$ Stochastic term.

The price of pulpwood was chosen as a variable to predict the behaviour of the wood pulp market because it had a significant influence on all market studies in general.

Polyakov et al. (2005) and Leuschner (1973) highlighted the importance of installed capacity in wood consumption determination. They mentioned the necessity of guaranteeing the supply of raw material since the production of these companies requires high fixed costs in their factories' installation. Therefore, managers must ensure that they operate continuously. Quantitative studies of these authors on the wood pulp market showed the low importance of the price of wood in the determination of demand, with models being proposed only with installed capacity as the main explanatory variable.

The installed capacity $\left(K_{t}\right)$ is expected to have a positive signal in relation to the demand for wood logs since an expansion or increase in its level of use, leading to increase in wood consumption.

The value of world imports of pulp $\left(\mathrm{VI}_{\mathrm{t}}\right)$ was used as proxy for the world income. If the total value is high and its evolution is increasing, it means that the importing countries have more purchasing power and would demand more pulp, which would imply a greater demand for timber from the pulp producers and exporters. Therefore, the variable value of world imports of pulp could explain the demand for pulpwood by pulp exporting countries.

It is expected that the variables capacity and value of world pulp imports are positively related with the demand. On the other hand, the price is negatively related to the demand for pulpwood for pulp production in Brazil between 1994 and 2016

In sum, it is expected for the demand for wood in logs that the coefficients $\beta_{0}, \beta_{2}$ and $\beta_{3}$ are greater than 0 and $\beta_{1}$ is less than 0 . One of the advantages of the function's logarithmic specification is that the elasticities are given directly by the values of $\beta_{i}$. The equation [1] was estimated using the Ordinary Least Squares (OLS) method used in conjunction with the Cocrane and Orcut method (1949), quoted by Gujarati (2000), 
to correct the serial correlation of the residues. The software used to estimate the demand regression was IBM SPSS Statistics and Eviews.

\section{Model evaluation}

As the specified model is identified, the Ordinary Least Squares (OLS) method was used. To test the significance of the regression obtained by the OLS, the $\mathrm{F}$ test was used, while the degree of adjustment of the regressions was evaluated by the coefficient of determination $\left(R^{2}\right)$. Thus, the demand equation presented more relevant variables than others, according to economic theory.

\section{Data}

The data used come from annual series and cover the period from 1994 to 2016, and the observations are expressed in indices, based on $2000(2000=100)$.

The size of the time series chosen is mainly justified by the availability of data and the representativeness of the sample. It is considered that the period of coverage is capable of capturing the behaviour of the pulpwood market in Brazil.

Data on the timber market in logs and the pulp and paper market in Brazil were collected directly on specific websites. The segments addressed in the research were: log-timber market, timber demand models for pulp production, production levels, installed capacity and value of world pulp imports.

The variables collected were:

- Total amount of wood logs for pulp marketed in year $t$ in Brazil $\left(Q_{t}\right)$. Data from SIDRA - IBGE / Silviculture Research (2018);

- The price of pulpwood for pulp production in year $t\left(P_{t}\right)$ : measured by the unit value of pulpwood revenue, calculated by the ratio of the total value of timber production for the year $t$ and the quantity marketed in the same year, in $R \$$, deflated by the General Price Index (IGP-DI / FGV). Data from SIDRA IBGE / Silviculture Research (2018);

- Installed capacity of the pulp industry in Brazil in year $t\left(\mathrm{~K}_{\mathrm{t}}\right)$, total pulp production in tons / year. IBGE data (2018);

- World value of imports of pulp in year $t\left(\mathrm{VI}_{\mathrm{t}}\right)$, deflated by CPI USA. FAO Data (2018).

\section{Evolution of quantity demanded for pulpwood}

Based on data from IBGE (2018), the quantity demanded for timber by the pulp and paper industry grew by $85 \%$ since 2000 , from 46 million to 85.2 million cubic meters in 2016. This growth was not continuous throughout the studied period, and reductions were observed in some years of the series. However, from 1997 onwards, a steady growth trend is observed. The increase in log consumption in this industry in the last decade is mainly due to the growth of exports in the first half of the decade of 2000, with strong exchange devaluation concomitant to a great world-wide growth led by China.

Some interruptions in the growth of wood logs consumption can be explained by changes in some variables that affect it, in particular: variability in the wood dependence of the market by the pulp and paper industry, pulp price and the magnitude of the installed capacity (Fig 1).

\section{Evolution of timber price}

The price of timber for pulp production is affected by several variables, including: international pulp prices; the imbalance between supply and demand, which is dubbed by the sector as "forest blackout"; the distance from the settlement to the factory; the oligopolistic power of the pulp industry; taxes and subsidies incidents; and the increased competition generated by the growth of the reconstituted panel industry (Leuschner, 1973, Adams, 1975, Brännlund et al., 1985, Kuuluvainen, 1986, Newman, 1987, Carter, 1992, Hetemäki and Kuuluvainen (1992; Polyakov et al. ., 2005).

There is no clear trend about the behaviour of real wood prices over the study period (Fig 2). After a period of slight stability in the 1990s, the 2000s witnessed a strong increase in prices, with a rise of $65.69 \%$ in eleven years, from $R \$ 15.21$ in 2000 to $\mathrm{R} \$ 25.20$ in cubic meters in 2011, which was the highest value recorded in the studied series, in 2000 prices (IBGE, 2018). This increase, among other factors, is explained by: expansion of the international economy and pulp exports; increase in exports of mechanical processing and consequent increase in competition for wood; effect of the substitution of Amazon's wood for that of reforestation due to environmental restrictions; and increased demand for forest wood for other uses, such as energy and the panel industry (Almeida, 2006).

In recent years, the price of wood pulp for pulp production was below the maximum registered in 2011, but above the average price of the 1990s. The slowdown of the national economy, reducing the demand for wood, was one of the factors for this reduction in price.

\section{Evolution of installed capacity}

The expansion of installed capacity showed a clear upward trend throughout the studied period (Fig 3). In the last sixteen years, the sector's growth reached $38.88 \%$. Pulp production in 2000 was of 6.9 million. In 2016 this number turned into 9.6 million tons (IBGE, 2018).

Polyakov et al. (2005) and Leuschner (1973) cite in the literature the importance of installed capacity in wood consumption. These authors mention that much more important than the price of wood for the paper and sheet metal industry is the guarantee of raw material supply since the production of these companies requires high fixed costs in the installation of their factories. Therefore, managers must ensure that they operate continuously. Quantitative studies of these authors on the wood pulp market showed the low importance of the price of wood in the determination of demand, with models being proposed only with installed capacity as the main explanatory variable.

\section{Evolution of world value of pulp imports}

In addition to the price of wood and installed capacity, the variable value of pulp imports can be considered as a determinant of wood consumption by pulp and paper companies, given the sector's export orientation.

According to BRACELPA (2009), Brazilian pulp production in 2008 totalled 12.8 million tons, of which 7.0 million tons were 
exported, about $55 \%$ of the national production. Effectively, between 1988 and 2013 there was an increase in the world value of imports of pulp (Fig 4), about 20\%. The years 1995, 2000 and 2010 are marked by sharp increases in import value, which jumped from \$29 million in 1998 to $\$ 35.4$ million in 2013 (FAO, 2015).

The variable world value of pulp imports can be used as a proxy for countries' income. It is important to take into account that, the higher the income of a country is, the greater the purchasing power will be. Therefore, it is expected that there is a greater demand of wood for pulp production when value of pulp imports raise.

\section{Conclusions}

The estimated demand equation has important implications for the timber market for pulp production in Brazil as well as in the design of policies that promote more rational and sustainable management of wood and consequently the forests. The demand for timber by the pulp industry can be explained by the price of pulpwood, installed capacity and value of world pulp imports. The amount of timber demanded by the pulp industry responded in elastically to changes in the price of wood in logs. The low price elasticity of demand for pulpwood for pulp production is compatible with the price elasticities studied in the literature on Brazil and the world.

\section{References}

ABIMCI (2007) Associação Brasileira da Indústria de Madeira Processada Mecanicamente. Estudo setorial - ABIMCl. Curitiba,. Disponível em: < http://www.abimci.com.br/wpcontent/uploads/2014/02/2007.pdf > Acesso em: 04/05/2015.

ABRAF (2013) Associação Brasileira de Produtores de Florestas Plantadas. Anuário estatístico ano base 2012 / ABRAF. Brasília: Disponível em: < handle/123456789/3910> Acesso em: 30/04/2015.

ABRAF (2011) Associação Brasileira de Produtores de Florestas Plantadas. Anuário estatístico ano base 2010 / ABRAF. Brasília. Disponível em: < handle/123456789/3910> Acesso em: 30/04/2015.

ABRAF (2010) Associação Brasileira de Produtores de Florestas Plantadas. Anuário estatístico ano base 2009 / ABRAF. Brasília Disponível em: < handle/123456789/3910> Acesso em: 30/04/2015.

Adams DMA (1075) Model of pulpwood production and trade in Wisconsin and the Lake States. Forest Science, Madison. 21(3):301-312.

Almeida AN (2006) Estudo econométrico da demanda e oferta de madeira em tora para o processamento mecânico no Estado do Paraná. 217p. Tese (Doutorado em Economia e Política Florestal) - Universidade Federal do Paraná, Curitiba, 2006.

Ângelo H, Serrano ALM, Almeida AN (2009) Determinantes da demanda de madeira em toras para celulose no Brasil. Sci For Piracicaba. 37(84): 491-498.

Antonangelo A, Bacha CJC (1998) As fases da silvicultura no Brasil. Revista Brasileira de Economia, Rio de Janeiro. 52(1): 207-209.

BRACELPA (2014) ASSOCIAÇÃO BRASILEIRA DE CELULOSE E
PAPEL. Anuário estatístico. São Paulo, 2014. Disponível em: < http://www.bracelpa.org.br/

bra/estatisticas/pdf/anual/rel2014.pdf>. Acesso em: 30/04/2015.

BRACELPA (2015) ASSOCIAÇÃO BRASILEIRA DE CELULOSE E PAPEL. Setor de celulose e papel, Conjuntura Bracelpa, 64. São Paulo, 2014.2 Disponível em: <http://bracelpa.org.br/bra2/?q=node/188>. Acesso em: 30/04/2015.

BRACELPA (2014) ASSOCIAÇÃO BRASILEIRA DE CELULOSE E PAPEL. Dados do Setor. São Paulo, março 2014. Disponível em: $\quad<$ http://www.bracelpa.org.br/bra/estatisticas/pdf/ booklet/março2014.pdf >. Acesso em: 20/03/2015.

BRACELPA (2008) ASSOCIAÇÃO BRASILEIRA DE CELULOSE E PAPEL. Anuário estatístico. São Paulo, 2008. Disponível em: < http://www.ipef.br/estatisticas/>. Acesso em: 30/04/2015.

BRACELPA (2007) ASSOCIAÇÃO BRASILEIRA DE CELULOSE E PAPEL. Anuário estatístico. São Paulo, 2007. Disponível em: < http://www.ipef.br/estatisticas/>. Acesso em: 30/04/2015.

CAMPOS, J. Cabotagem Industrial no Transporte de Madeira em Toras. Logística e Comunicação, 6 de dezembro de 2011. Disponível em:

http://logisticaecomunicacao.blogspot.com.br/2011/12/cab otagem-industrial-no-transporte-de.html >. Acesso em: 30/04/2015.

FAO (2015) Organização das Nações Unidas para a Agricultura e Alimentação. Valor de importação de celulose. Disponível em:< http://faostat.fao.org/site/626/default.aspx\#ancor> . Acesso em 13/05/2015

Ferreira TC, Oliveira AD, Scolforo JRS, Rezende JLP (2004) Rotação econômica de plentios de Eucalyptus grandis para a produção de celulose. Cerne, Lavras. 10(2): 222-241.

Ferreira CA, Silva HD 92008) Formação de povoamentos florestais. Colombo Embrapa Florestas. 2008.

IPEADATA (2015) Banco de dados do Instituto de Pesquisa Econômica Aplicada. >Macroeconômico>séries históricas>preço>IGP-DI. Disponível em http://www.ipeadata.gov.br/> acesso em 10/06/2015.

IBGE (2013) Instituto Brasileiro de Geografia e EstatísticaSIDRA - IBGE/ Pesquisa da Silvicultura (2013); Tabelas 291 and $292 . \quad$ Disponível em:<http://www.sidra.ibge.gov.br/bda/tabela/listabl.asp?

$z=t \& o=1 \& i=P \& e=\mid \& c=2912015>$. Acesso em 13/05/2015

IBÁ (2014) Indústria Brasileira de Árvores. Relatório Vitória, 2014. Disponível em: < http://www.iba.org/images/shared/iba_2014_pt.pdf/>.

Acesso em: 30/06/2015.

Kuuluvainen J (1986) An econometric analysis of the sawlog market in Finland. Journal of World Forest Resource Management. 2:1-19.

Leuschner WA (1973) An econometric analysis of the Wisconsin Aspen pulpwood market. Forest Science. 19(1):4146.

Marques GM (2012) Determinantes do Preço da Madeira para Produção de Celulose no Brasil, 111f., 210 x 297 mm. Dissertação de Mestrado - Universidade de Brasília. Brasília.

Mokfienski A, Colodette JL, Gomide JL, Carvalho AMML (2008) A Importância Relativa da Densidade da Madeira e do Teor de Carboidratos no Rendimento de Polpa e na Qualidade do Produto. Ciência Florestal. 18(3):401-413. 
Newman DH (1987) An econometric analysis of the southern softwood stumpage market: 1950 1980. Forest Science. 33(4):932-945.

Polyakov M, Teeter LD, Jackson JD (2005) Econometric analysis of Alabama's pulpwood market. Forest Products Journal. 55(1):41-44.

Serrano ALM (2008) Análise Econométrica do Mercado de Madeira em Tora para Produção de Celulose. 83f., 210 × 297 mm. Dissertação de Mestrado - Universidade de Brasília. Brasília.
Soares TS, Valeii AB, Leiteii HG, Machado CC (2003) Otimização de multiprodutos em povoamentos florestais. Rev Árvore Viçosa. 27(6).

Soares NS, Oliveira RJ, Carvalho KHA, Silva ML, Jacovine LAG, Valverde SR (2010) A Cadeia Produtiva da Celulose e do Papel no Brasil. Floresta, Curitiba. 40(1):1-22.

SNIF (2015) Sistema Nacional de Informações Florestais. As florestas plantadas. Brasília, Disponível em:<http://www.florestal.gov.br/snif/recursos-florestais/asflorestas-plantadas/>.Acesso em: 30/04/2015. 